УДК 342.924

\author{
О. А. Мілієнко \\ orcid.org/0000-0002-3364-1774 \\ кандидат юридичних наук, \\ здобувач кафедри адліністративного та господарського права \\ Запорізького національного університету
}

\title{
ЄВРОПЕЙСЬКІ ТА СВІТОВІ СТАНДАРТИ ЗДІЙСНЕННЯ ПРОЦЕДУРИ ПРИЙНЯТТЯ АДМІНІСТРАТИВНИХ АКТІВ
}

Актуальність теми. Вимогою інтеграційних прагнень України в європейський правовий простір є докорінне реформування правової системи та наближення іiі до європейських стандартів. Саме за рахунок впровадження європейських стандартів забезпечується можливість наближення правових систем, що є ключовим чинником гармонізації національного законодавства та законодавства Європейського Союзу. Адаптація національного законодавства до системи права Європейського Союзу - це перший етап тривалого процесу наближення національної системи права, яка серед іншого включає доктрину та судову й адміністративну практику.

Ступінь наукової розробки. Загалом вивчення ідеї формування публічно-сервісної держави було предметом досліджень низки вчених. Так, виділяються праці О. Пушняка, О. Пономаренка, М. Щирби, О. Плечій та інших. Концепцію "good governance" досліджували у своїх працях українські вчені В.П. Тимощук, В.М. Бевзенко, С.П. Рабінович, Т.О. Коломоєць, І.С. Козій. 3 огляду на те, що європейські та світові стандарти здійснення процедури прийняття адміністративних актів досліджуються досить фрагментарно, доцільно проаналізувати це питання комплексно.

Мета роботи - здійснення характеристики європейських і світових стандартів здійснення процедури прийняття адміністративних актів.

Виклад основного матеріалу. Обов'язковим елементом правової системи будь-якої демократичної держави є законодавче регулювання відносин органів публічної адміністрації з фізичними та юридичними особами. Як свідчать дослідження окремих авторів, протягом другої половини XX ст. у більшості європейських країн відбувалася систематизація законодавства про адміністративну процедуру, наслідком чого стало прийняття окремих законодавчих актів. Зокрема, до таких держав належать Австрія, Польща, Угорщина, Icпанія, ФРН, Данія, Болгарія, Італія, Нідерланди, Португалія, Естонія, Латвія. Нині кілька держав колишнього СРСР також прийняли загальні закони про адміністративну процедуру (Азербайджан, Білорусь, Вірменія, Грузія, Казахстан). Доцільно зазначити, що в науковій літературі виникнення адміністративного процедурного права у Європі пов'язують із процесом кодифікації законодавства про адміністративну процедуру у 20 -х роках $\mathrm{XX} \mathrm{ст.} \mathrm{[1,} \mathrm{с.} \mathrm{24].}$

При прийнятті адміністративних рішень, тобто рішень органів публічної адміністрації, які стосуються прав і обов'язків конкретних приватних осіб, необхідно забезпечити такі права особи: бути вислуханою перед прийняттям негативного (несприятливого) рішення; на допомогу та представництво; на ознайомлення 3 матеріалами справи; обов'язки адміністративного органу обгрунтовувати несприятливі акти та зазначати порядок їх оскарження тощо. Ці та інші права особи й обов'язки адміністративних органів зафіксовано у законах про загальну адміністративну процедуру [2, с. 178].

На сучасному етапі наша держава активно рухається в напрямі інтеграції до європейського простору. На необхідності законодавчого врегулювання відносин органів публічної адміністрації з фізичними та юридичними особами наголошується в Угоді про асоціацію між Україною та ЄС [3]. Зокрема, ст. 1 Угоди про асоціацію між Україною та Європейським Союзом до основних цілей асоціації віднесено посилення співробітництва у сфері юстиції, свободи та безпеки з метою забезпечення верховенства права та поваги до прав людини і основоположних свобод.

$\mathrm{y}$ межах реалізації зазначених цілей актуальними $є$ питання наближення національного адміністративного законодавства та практики його застосування до законодавства ЄС. Так, у преамбулі до Угоди про асоціацію йдеться про важливість для досягнення поставлених нею цілей, тісного співробітництва в рамках Організації Об'єднаних Націй (далі - ООН), ОБСЄ та Ради Європи (далі $\mathrm{P€).} \mathrm{Адже} \mathrm{адаптація} \mathrm{вимог} \mathrm{ключових} \mathrm{документів,}$ укладених в межах цих структур, також сприятиме приведенню вітчизняної практики до європейських стандартів.

Як слушно вказується у спеціальній літературі, право на оскарження є важливим складником забезпечення відповідальності суб'єктів владних повноважень перед населенням. Воно визнається одним із базових принципів адміністративного права у Європі та знаходить свій вияв у 
багатьох документах Ради Європи та практиці Європейського суду з прав людини [4]. Так, Директивою № 1382/2013 Європейського парламенту та Ради від 17 грудня 2013 року щодо створення програми правосуддя на період із 2014 по 2020 рік акцентовано увагу як на питаннях забезпечення доступу до судових процедур, так і на можливостях використання альтернативних методів врегулювання спорів.

Зокрема, до основних і значимих документів Ради Європи щодо проблем оскарження та здійснення процедури прийняття адміністративних актів науковці відносять такі:

1. Резолюцію (77)31 Комітету міністрів Ради Європи державам-членам про захист особи відносно актів адміністративних органів від 28 вересня 1977 року (далі - Резолюція (77)31) [5];

2. Рекомендацію $\mathrm{R}(80) 2$ Комітету міністрів Ради Європи державам-членам щодо здійснення дискреційних повноважень адміністративними органами від 11 березня 1980 року (далі - Рекомендація R (80)2) [6];

3. Рекомендацію R (91)1 Комітету міністрів Ради Європи державам-членам стосовно адміністративних санкцій від 13 лютого 1991 року (далі - Рекомендація R (91)1) [7];

4. Рекомендацію Rec (2001)9 Комітету міністрів Ради Європи державам-членам стосовно альтернативних методів врегулювання спорів між адміністративними органами і приватними особами від 05 вересня 2001 року [8];

5. Рекомендацію Rec (2003)16 Комітету міністрів Ради Європи державам-членам про виконання адміністративних рішень і судових рішень у сфері адміністративного права від 09 вересня 2003 року [9].

Резолюція (77)31 (далі - Резолюція) визнається найбільш вагомою в аспекті розуміння поняття «адміністративного акту», яка закріплює широкий підхід до цього поняття та включає не лише акти адміністративних органів влади, але й будьякі рішення, які за своїм характером безпосередньо впливають на права або зачіпають інтереси публічних осіб під час здійснення публічної влади. Саме вказана Резолюція містить основні критерії відмежування адміністративних актів від інших актів, зокрема, вказуючи на те, що такі акти приймаються у зв'язку зі здійсненням публічно-владних повноважень незалежно від того, чи є суб'єктом цих повноважень орган державної влади або ж будь-який інший орган чи особа, яким ці повноваження делеговано. Утім у п. 10 пояснювальної записки до Резолюції вказано, що у разі, якщо адміністративний акт, наданий у письмовій формі, несприятливо впливає на права, свободи або інтереси особи, то в ньому зазначаються звичайні засоби правового захисту проти такого впливу, а також строки для їх використання. Крім того, нею не охоплюються адміністративні акти, які приймаються за наслідками кримінального розслідування, судової процедури та законодавчого процесу [10].

Відповідно до п. 34 пояснювальної записки до Резолюції (77)31 до звичайних засобів не належить конституційна скарга, звернення до омбудсмена чи міжнародних судових установ тощо. Такі засоби включають у себе звернення до органів, які компетентні переглядати адміністративні акти у судовому й позасудовому порядку [4]. У п. 28 цієї записки вказується на необхідність мотивування ухваленого адміністративного акту, оскільки саме мотиви, якими керувався адміністративний орган при прийнятті такого акту, є передумовою для вирішення питання необхідності його оскарження.

Рекомендацією R (80)2 закріплюється, що акт, прийнятий під час здійснення дискреційних повноважень, підлягає контролю щодо його законності з боку суду чи іншого незалежного органу. Такий контроль не виключає можливості попереднього контролю з боку адміністративного органу, уповноваженого приймати рішення щодо його законності та суті справи. Таким чином, контроль за адміністративними актами може відбуватися в порядку поступового адміністративного і судового оскарження цих актів, причому обов'язкова адміністративна скарга відповідно до Рекомендації $\mathrm{R}(80) 2$ не є порушенням європейських стандартів за умови, що відомчий контроль не перешкоджає судовому [10].

Пунктами 7, 10 Додатку до Рекомендації R (80)2 закріплюється доцільність мотивування адміністративних актів щодо права контролюючих органів на отримання інформації, пов'язаної 3 ухваленням певного адміністративного рішення. Метою контролю за адміністративними актами згідно з п. 43 Додатку до Рекомендації R (80)2, $€$ забезпечення їх законності та «якісності» .

На жаль, Рекомендація R (80)2 фактично не формулює та розкриває, що доцільно розуміти під якістю адміністративного акту, але окремі автори припускають, що йдеться, зокрема, про вимоги щодо розумності, добросовісності, пропорційності, розсудливості, які безпосередньо випливають із верховенства права. Це означає, що законність при оскарженні подібних актів не має формально тлумачитися контролюючими органами; скаржнику має бути гарантована можливість посилатися не тільки на невідповідність акту окремій нормі закону, але й на порушення наведених вище принципів, які призвели до зниження «якості» адміністративного акту [4].

Рекомендаціями $\operatorname{Rec}$ (2001)9 акцентовано увагу на важливій ролі позасудових засобів врегулювання спорів. Саме це $є$ передумовою для полегшення доступу до правосуддя і зменшення надмірного навантаження на суди. Крім того, ця 
рекомендація, як і Рекомендація R (80)2, передбачає, що внутрішній розгляд може бути обов'язковим і передувати зверненню до суду (розділ III Додатку до Рекомендації Rec (2001)9) [10]. Необхідно зазначити, що в Рекомендації Rec (2001)9 згадано про низку способів врегулювання спорів за участю адміністративних органів: внутрішній розгляд, мирова угода, арбітраж, примирення. Нині в аспекті проблем оскарження в Україні функціонує лише інститут внутрішнього розгляду і обговорюється можливість запровадження арбітражу (третейського розгляду) й примирення у публічно-правових справах [11].

Рекомендація (2003)16 містить положення, які стосуються наслідків оскарження особою адміністративного акту. Крім того, вона наголошує на обов'язку держави у розумний строк забезпечити виконання судових рішень, ухвалених щодо адміністративних органів.

Рекомендація R (91)1 (далі - Рекомендація) закріплює положення про притягнення до адміністративної відповідальності за правопорушення, передбачені КУпАП, і накладення відповідних стягнень, а саме щодо оскарження рішень про застосування таких стягнень. Вказана Рекомендація вказує на те, що перегляд рішень про застосування адміністративних стягнень включає в себе перегляд справи по суті.

Лише наведеними документами Ради Свропи досліджувана проблематика не вичерпується. Зокрема, Рекомендація R (84)5 Комітету міністрів Ради Європи державам-членам про принципи цивільного судочинства, спрямовані на удосконалення судової системи, від 28 лютого 1984 року [12] хоч і не має прямого відношення до судового адміністративного процесу, проте їі положення можуть бути використані як відправні засади розвитку законодавства, яке регламентує здійснення правосуддя в адміністративних справах.

Практика Європейського суду з прав людини має важливе значення в аспекті розуміння європейських стандартів адміністративно-правового оскарження. Варто вказати, що згідно зі ст. 17 Закону України «Про виконання рішень і застосування практики Європейського суду з прав людини" [13] як джерело права суди при розгляді справ застосовують Конвенцію про захист прав людини і основних свобод та практику ЄСПЛ. Крім того, КАС України на підставі розуміння верховенства права також вимагає врахування практики Європейського суду. Як вказують окремі дослідники, це означає, що аналіз рішень суду має доктринальне значення та слугує основою для покращення правового регулювання, але й підлягає безпосередньому використанню суддями у процесі вирішення справ. Саме через це він впливає на практику органів, які здійснюють публічне управління [4].
Адміністративно-правова проблематика, яка стосується багатьох статей «Конвенції про захист прав людини і основоположних свобод» (далі Конвенція), часто зустрічається у практиці суду. Стаття 13 Конвенції закріплює, що кожен, чиї права та свободи, визнані в ній, було порушено, має право на ефективний засіб юридичного захисту в національному органі, навіть якщо таке порушення було вчинене особами, які здійснювали свої офіційні повноваження. Практика ЄСПЛ також має безпосередне відношення до питань судового і позасудового захисту прав і законних інтересів приватних осіб. Стаття 1 Першого Протоколу до Конвенції передбачає, що кожна фізична або юридична особа має право мирно володіти своїм майном. Ніхто не може бути позбавлений своєї власності інакше як в інтересах суспільства і на умовах, передбачених законом і загальними принципами міжнародного права.

Аналіз положень ст. 6 Конвенції свідчить, що вона поширюватиметься саме на справи, які розглядаються в порядку кримінального й цивільного судочинства. Про адміністративні ж справи не йшлося [5, с. 421]. Проте з пливом часу ЄСПЛ своє розуміння ст. 6 поступово розширював. Зокрема, у справі «Цимерман і Штайнер проти Швейцарії» суд вказав, що у цьому випадку права заявників підпадають під дію ст. 6 Конвенції, оскільки вони по суті є приватними [15]. Той самий підхід можна побачити і у справі «Церква села Сосулівка проти України». Крім того, доцільно вказати й на справи «OVR проти Російської Федерації» [16]; «Фельдебрюгге проти Нідерландів» [17]; «Гавриленко проти Російської Федерації» щодо нарахування та індексації соціальних пільг тощо [18]. ЄСПЛ вказав, що деякі справи щодо притягнення до адміністративної відповідальності можуть підпадати під дію ст. 6 Конвенції, якщо проступки, визначені в національному законодавстві як адміністративні, за своєю природою є кримінально-правовими або характер обтяжень, які накладаються на особу, серйозні настільки, що фактично дорівнюють кримінальній відповідальності [19].

Висновки. В аспекті наведеного ми погоджуємося 3 тими вченими, які вказують, що «європейські стандарти у сфері адміністративного оскарження перетворилися на досить складний комплекс вимог, які накладаються на державу як у вимірі правового регулювання таких питань, так і щодо забезпечення належного функціонування судової влади та доступу до правосуддя» [4]. Для більш високого рівня уніфікованого регулювання з метою усунення юридичних колізій або "підготовки» певної сфери суспільних відносин у правових стандартах, які встановлюються у сферах правового регулювання, необхідно типологізувати поведінку відповідних суб'єктів права [20]. 


\section{Jimepamypa}

1. Люхтергандт О. Проект Адміністративного процедурного кодексу України та сучасне адміністративне процедурне право. Юридичний журнал. 2002. № 5. С. 24.

2. Адміністративна процедура та адміністративні послуги. Зарубіжний досвід і пропозиції для України / Автор-упорядник В.П. Тимощук. К. : Факт, 2003. C. $178-459$.

3. Угода про асоціацію між Україною, з однієї сторони, та Європейським Союзом, Європейським співтовариством з атомної енергії і їхніми державами-членами, з іншої сторони від 27.06.2014. Режим доступу: https://zakon.rada.gov.ua/laws/show/984_011.

4. Лученко Д.В. Європейські стандарти у сфері оскарження рішень, дій або бездіяльності суб'єктів владних повноважень.URL:luchenko_d_v_yevropeiski standarty_u_sferi_oskarzhennia_rishen_dii_ab_ bezdiialnosti_subiektiv_vladnykh_povnovazhen.pde $\overline{\text {. }}$.

5. Рада Європи. Резолюція (77)31 Комітету міністрів державам-членам про захист особи щодо актів адміністративних органів від 28.09.1977. Ліга. Закон : комп'ютер.-прав. система. Всеукр. мережа розповсюдження прав. інф. Версія 8.2.3. Київ, 2012.

6. Рада Європи. Рекомендація R (80)2 Комітету міністрів державам-членам щодо здійснення дискреційних повноважень адміністративними органами від 11.03.1980. Ліга. Закон : комп'ютер.-прав. система. Всеукр. мережа розповсюдження прав. інф. Версія 8.2.3. Київ, 2012.

7. Рада Європи. Рекомендація R (91)1 Комітету міністрів державам-членам стосовно адміністративних санкцій від 13.02.1991 // Ліга. Закон : комп'ютер. прав. система. Всеукр. мережа розповсюдження прав. інф. Версія 8.2.3. Київ, 2012.

8. Рада Європи. Рекомендація Rec (2001)9 Koмiтету міністрів Ради Європи державам-членам стосовно альтернативних методів врегулювання спорів між адміністративними органами і приватними особами від 05.09.2001. Ліга. Закон : комп'ютер.-прав. система / Всеукр. мережа розповсюдження прав. інф. Версія 8.2.3. Київ, 2012.

9. Рада Свропи. Рекомендація Rec (2003)16 Комітету міністрів державам-членам про виконання адміністративних рішень і судових рішень у сфері адміністративного права від 09.09.2003. Ліга. Закон : комп'ютер.-прав. система / Всеукр. мережа розповсюдження прав. інф. Версія 8.2.3. Київ, 2012.

10. Лученко Д.В. Інститут оскарження в адміністративному праві : дис. д-ра юрид. наук: 12.00.07 / Д.В. Лученко; наук. конс. Ю.П. Битяк; Нац. юрид. ун-т ім. Ярослава Мудрого. Харків, 2017. 457 с.

11. Сало Л. Медіація як спосіб альтернативного вирішення окремих публічно-правових спорів. Проблеми державотворення $i$ захисту прав люди ни в Україні : матер. XVI регіон. наук.-практ. конф., 8-9 лютого 2010 року. Л. : Юрид. ф-т Львів. нац. ун-ту, 2010. C. $140-142$.

12. Рада Європи. Рекомендація R (84)5 Комітету Міністрів державам-членам про принципи цивільного судочинства, спрямовані на удосконалення судової системи від 28.02.1984. Ліга. Закон : комп'ютер.-прав. система. Всеукр. мережа розповсюдження прав. інф. Версія 8.2.3. Київ, 2012.

13. Про виконання рішень та застосування практики Європейського суду з прав людини : Закон України від 23.02.2006 № 3477-IV. Відомості Верховної Ради України. 2006. № 30. Ст. 260 (з наст. змінами і допов.).

14. Адміністративна юстиція України: проблеми теорії і практики. Настільна книга судді / за загальною редакцією О.М. Пасенюка. К. : Істина, 2007. С. 421.
15. Рішення ЄСПЛ у справі «Цимерман і Штайнер проти Швейцарії” від 20.06.1983. Ліга. Закон : комп'ютер.-прав. система. Всеукр. мережа розповсюдження прав. інф. Версія 8.2.3. Київ, 2012.

16. Рішення ЄСПЛ у справі «OVR проти Російської Федерації від 20.06.2000. Ліга. Закон : комп’ютер.прав. система. Всеукр. мережа розповсюдження прав. інф. Версія 8.2.3. Київ, 2012.

17. Адміністративна юстиція України: проблеми теорії і практики. Настільна книга судді. За загальною редакцією О.М. Пасенюка. К. : Істина, 2007. 421 с.

18. Рішення ЄСПЛ у справі «Гавриленко проти Російської Федерації». URL: http://www1.umn.edu/ humanrts/russian/euro/Rgavrilenkocase.html.

19. Бойко І.В. Застосовуваність статті 6 Конвенції про захист прав людини і основоположних свобод при розгляді справ про адміністративні правопорушення. Вісник Національної академї прав. наук. 2016. № 2(85). C. 59-71.

20. Решота В.В. Європейські стандарти адміністративної юстиціï. URL: http://academy.gov.ua/ej/ej3/ txts/POLITICHNI/07-RESCHOTA.pdf.

\section{Анотація}

Мілієнко О. А. Свропейські та світові стандарти здійснення процедури прийняття адміністративних актів. - Стаття.

Метою наукової роботи визначено здійснення характеристики європейських і світових стандартів процедури прийняття адміністративних актів. 3'ясовано, що інтеграція України в європейський правовий простір вимагає докорінного реформування правової системи та приведення іiї у відповідність до стандартів європейських інституцій.

Визначено, що європейські стандарти є тими вимогами, які забезпечують наближення правових систем і $€$ важливим засобом гармонізації законодавства України та Європейського Союзу. Підкреслено, що адаптація законодавства України до системи права Європейського Союзу відповідно до критеріїв, які висуваються ЄС щодо держав, які мають намір приєднатися до нього, це перший етап тривалого процесу наближення національної системи права, яка серед іншого включає доктрину та судову й адміністративну практику.

Визначено, що контроль за адміністративними актами може відбуватися в порядку поступового адміністративного і судового оскарження цих актів, причому обов' язкова адміністративна скарга відповідно до Рекомендації R (80)2 не є порушенням європейських стандартів за умови, що відомчий контроль не перешкоджає судовому. Визначено, що Рекомендація (2003)16 містить положення, які стосуються наслідків оскарження особою адміністративного акту.

Зроблено висновок, що європейські стандарти у сфері адміністративного оскарження перетворилися на досить складний комплекс вимог, які накладаються на державу як у вимірі правового регулювання цих питань, так і щодо забезпечення належного функціонування судової влади та доступу до правосуддя. Обгрунтовано, що правові стандарти встановлюються у сферах правового регулювання, в яких необхідно типологізувати поведінку відповідних суб'єктів права з метою усунення юридичних колізій або «підготовки» певної сфери суспільних відносин для більш високого рівня уніфікованого регулювання.

Ключові слова: адміністративний акт, адміністративне оскарження, правозастосування, суб'єкт владних повноважень, юрисдикція. 


\section{Summary}

Milienko O. A. European and public standards for the procedure for accepting administrative acts. Article.

The purpose of scientific work is to implement the characteristics of European and world standards of procedure for the adoption of administrative acts. It was found that the integration of Ukraine into the European legal space requires a radical reform of the legal system and bringing it in line with the standards of European institutions.

It is determined that European standards are the requirements that ensure the approximation of legal systems and are an important means of harmonizing the legislation of Ukraine and the European Union. It was emphasized that the adaptation of Ukrainian legislation to the European Union legal system in accordance with the criteria set by the European Union for states intending to join it is the first stage of a long process of approximation of the national legal system, which includes doctrine and judicial and administrative practice.
It is determined that control over administrative acts can take place in the order of gradual administrative and judicial appeal of these acts and a mandatory administrative complaint is not, according to Recommendation $\mathrm{R}(80)$ 2, a violation of European standards, provided that departmental control does not interfere with judicial.

Recommendation (2003) 16 states that it contains provisions concerning the consequences of a person's appeal against an administrative act. It is concluded that European standards in the field of administrative appeal have become a rather complex set of requirements imposed on the state both in terms of legal regulation of these issues and in ensuring the proper functioning of the judiciary and access to justice. It is substantiated that legal standards are established in the areas of legal regulation, in which it is necessary to typify the behavior of the relevant subjects of law in order to eliminate legal conflicts or "prepare" a certain area of public relations for a higher level of unified regulation.

Key words: administrative act, administrative disclaimer, legal protection, subordinate ownership, jurisdiction. 